Experimental Station at Harpenden, Herts; and Dr. Jacobo Zender, director-general of agriculture at the Ministry of Agriculture, Peru.

Commonwealth Fund Fellowships for Advanced Study and Travel in the United States

A NuMBer of Commonwealth Fund fellowships are again being offered by the Commonwealth Fund of New York (1 East 75th Street, New York 21) to British subjects, for advanced study and travel in the United States. All expenses of travel, study and living will be met, with some adjustment of stipends for married men with families. The fellowships, which are open to British men and women who are not normally resident in or near the Americas and who have not previously worked or studied for more than a few months in the United States, are offered annually in six categories as follows. General : twenty fellowships to graduates of a university in the United Kingdom of Great Britain and Northern Ireland. Candidates must be available in London for interview in March 1953; age, 23-35; tenure, 12-21 months ; applications by December 15. Home Civil Service: five fellowships to permanent members in the higher ranks of the Civil Service in Great Britain, three for the administrative grades and two for the scientific and professional grades; age, less than 40 ; tenure, 6-12 months; applications by December 31 . Dominion Civil Service: five fellowships to Civil servants in the Governments of Australia, New Zealand and South Africa; age, less than 40; tenure, 1221 months; applications by December 31 . Colonial Civil Service: two fellowships to Civil servants in the Governments of British Colonies, Protectorates and Trust Territories; age, less than 40 ; tenure, 6-12 months ; applications by November 15. Journalism: three fellowships to journalists practising in the United Kingdom and engaged on the opinion-making or broadly editorial side of their profession; age, 23-35; tenure, 9-15 months; applications by December 31. American Studies: four fellowships will be available to faculty members appointed to or holding posts in American studies in universities in the United Kingdom, candidates to be nominated by their universities; tenure, 4-12 months (these fellowships are not limited by previous study in the United States). Application forms and further details of these fellowships can be obtained in Britain through universities or government departments, or from the Warden, Commonwealth Fund, Harkness House, 35 Portman Square, London, W.1.

\section{Nature Conservancy Research Studentships}

The Nature Conservancy has made the following awards for 1952 of research studentships for postgraduate training in ecology, tenable for periods up to three years at the institutions indicated : Botany, B. N. Bowden (Lincoln College, Oxford), Miss B. Douglas (Freshwater Biological Association, Ferry House, near Ambleside), J. D. Lovis (University of Leeds), K. J. F. Park (King's College, Newcastle upon Tyne) and I. H. Rorison (University College, Oxford) ; Zoology, A. B. Acton (Keble College, Oxford), J. M. Cullen (Wadham College, Oxford), M. J. Davies (Exeter College, Oxford), and A. M. Jordan and D. H. Murphy (University of Durham); Physiography, D. H. Maling (University of Durham).

\section{The Night Sky in October}

FULL moon occurs on Oct. 3d. 12h. 15m., U.T., and new moon on Oct. 18d. 22h. 42m. The following conjunctions with the moon take place: Oct. 6d. 10h., Jupiter $7^{\circ}$ S. ; Oct. 20d. 10h., Mercury $4^{\circ}$ N.; Oct. 21d. 15h., Venus $4^{\circ}$ N. ; Oct. 24d. 11h., Mars $1^{\circ} \mathrm{N}$. Mercury is too close to the sun during most of the month for favourable observation. Venus, an evening star, sets at $18 \mathrm{~h} .25 \mathrm{~m} ., 18 \mathrm{~h} .0 \mathrm{~m}$. and $17 \mathrm{~h}$. $50 \mathrm{~m}$. on October 1,15 and 31 , respectively. Its stellar magnitude is $-3 \cdot 4$, and $0 \cdot 90-0 \cdot 83$ of the illuminated disk is visible. Mars is an evening star, setting at $20 \mathrm{~h} .10 \mathrm{~m}$. in the middle of October and only ten minutes later and earlier at the beginning and end of the month, respectively; the stellar magnitude varies between $0 \cdot 6$ and $0 \cdot 8$. Jupiter rises at $19 \mathrm{~h} .10 \mathrm{~m}$. on October 1 and about two hours earlier at the end of the month. Its stellar magnitude is $-2 \cdot 4$, and during October it is a little south of $\delta$ Arietis. Saturn is in conjunction with the sun on October $\mathrm{Il}$ and is unfavourably placed during the month for observation. Occultations of stars brighter than magnitude 6 are as follows : Oct. 5 d. $20 \mathrm{~h} .08 \cdot 9 \mathrm{~m}$., $\mu$ Arie. $(R)$; Oct. 6d. 21h. 53.5m., 17 Taur. $(D)$; Oct. 6 d. $22 \mathrm{~h} .10 \cdot 6 \mathrm{~m} ., q$ Taur. $(D)$; Oct. $6 \mathrm{~d} .22 \mathrm{~h}$. 18.4m., 20 Taur. $(D)$; Oct 6 d. $22 \mathrm{~h} .37 \cdot 5 \mathrm{~m}$., 17 Taur. $(\boldsymbol{R})$; Oct. 6d. $22 \mathrm{~h} .5 \mathrm{l} \cdot 8 \mathrm{~m} ., 16$ Taur. $(R)$; Oct. $6 \mathrm{~d}$. 23h. 06.3m., $q$ Taur. $(R)$; Oct. 6d. 23h. 22.Im., 20 Taur. $(R)$; Oet. 6d. $23 \mathrm{~h} .26 \cdot 9 \mathrm{~m} ., 21$ Taur. $(R)$; Oct. 29d. 0h. $21 \cdot 4 \mathrm{~m}$., 232 B.Aquar. $m(D)$; Oct. 30d. $20 \mathrm{~h} .04 \cdot 3 \mathrm{~m}$., 51 Pisc. $(D) . \quad D$ and $R$ refer to disappearance and reappearance, respectively, and observations are for Greenwich. The Orionid meteor shower occurs about October $20-23$; the radiant of this shower is at R.A. $6 \mathrm{~h} .24 \mathrm{~m}$., dec. $15^{\circ}$. The supposed connexion between this stream and Halley's Comet has been disproved by the work of Prof. A. C. B. Lovell, of Manchester, who has shown from a determination of the velocity of meteors from the shower that the period must be comparatively short and hence the shower cannot be associated with Halley's Comet, the period of which is about 76 years. The same conclusion applies to the $\eta$ A.quarids early in May, which were also believed to be associated with Halley's Comet.

\section{Announcements}

THE sixth Rutherford Lecture of the Physical Society will be given on October 3 at 5.10 p.m. in the Lecture Theatre of the Science Museum, London, S.W.7, by Prof. R. E. Peierls, professor of theoretical physics in the University of Birmingham; he will speak on "The Atomic Nucleus and its Constituents".

AT an open day which is being held at the Fulmer Research Institute, Stoke Poges, Bucks, on September 30 , a memorial plaque to the founder, Colonel W. C. Devereux, will be unveiled by Lord Hives, of Rolls Royce, Ltd.

By an Order of the Committee of Privy Council for Medical Research, Sir Geoffrey Vickers has been appointed to be a member of the Medical Research Council. By the same Order made in this respect after consultation with the Medical Research Council and with the President of the Royal Society, the following have also been made members of the Council : Prof. G. R. Cameron, professor of morbid anatomy in University College Hospital Medical School, London; Prof. A. J. Lewis, professor of psychiatry in the University of London; and Sir James Spence, Nuffield professor of child health in the University of Durham. 